\title{
CLASSIFICATION OF FINANCIAL MECHANISMS OF HEALTHCARE SYSTEMS IN THE COUNTRIES OF EUROPEAN UNION
}

\author{
Nadiya Dubrovina ${ }^{1}$ \\ Stanislav Filip ${ }^{2}$ \\ Vira Dubrovina ${ }^{3}$
}

DOI: https://doi.org/10.31410/ITEMA.2020.169

\begin{abstract}
In the article the problems of the classification of financial mechanisms of healthcare systems were considered. The well-known types of the financial mechanisms of healthcare systems were described and the authors argued the importance of the development of new classification of financial mechanism of healthcare systems in the EU, which will be based on the application of quantitative methods. The purpose of the research is cluster (or regimes of funding healthcare system) analysis and development for EU countries over longterm period of 2000-2017.The authors used k-means method for the cluster analysis and revealed 5 clusters (groups) for the characteristics of the different regimes of funding healthcare system in the EU countries.
\end{abstract}

Keywords: Healthcare system, Funding, Classification, Cluster analysis.

\section{INTRODUCTION}

$\mathrm{H}$

ealth of population is a highest value of citizens in the developed democratic countries and the one of the prior target of social policy of the governments in the EU countries (European Commission, 2010). One of the important task for the government is to develop an efficient mechanism of funding healthcare based on the optimal allocation of public resources, social equity and access to the main healthcare services needed for support of public and individual health, prevention and treatment of the diseases, high quality of the health services and good performance of the healthcare institutions. For these reasons strategies of health policy should be based on the targets of society, in one of the hand, and features of the socio-economic capacities and political background, in other hand. Health policy as a mirror of the values of the society or communities, and it is relative with socio-economic systems, traditions, national strategical programs of the development, etc. (Greer et al, 2013, Gottlieb et al, 2019).

Kostičová et al. noted that "a health system is the ensemble of all public and private organizations, institutions and resources mandated to improve, maintain or restore health" (Kostičová et al, 2011, p. 84.). That is why is relatively difficult to compare national health systems in the different countries, because it is necessary to take into account main indicators

School of Economics and Management in Public Administration in Bratislava, Furdekova 16, 85104 Bratislava, Slovakia

2 School of Economics and Management in Public Administration in Bratislava, Furdekova 16, 85104 Bratislava, Slovakia

3 Kharkiv Institute of Trade and Economics of KNTEU, Otakara Yarosha Ln, 8, Kharkiv, Kharkiv, 61000, Ukraine 
characterizing economic, socio-demographic, political and institutional background in each country. Nevertheless, some typologies or classification of the healthcare systems to its funding are described in the books and papers (Mossialos et al, 2002, Kostičová et al, 2011, Benova et al., 2014). The authors characterize well-known types of the financing of health systems as: Bismarkian health insurance or public contract model, Beveridge model or public-integrated model, Douglas national health insurance model, Semashko national health system or mixed private/public system (Kostičová et al, 2011), or develop own classification based on the multidimensional analysis of the set of the main indicators characterizing health systems (Benova et al., 2014). Beveridge model is based on the public finance by general taxation. This model is implemented in the UK, Norway, Sweden, Denmark, Italy, Spain, Portugal, Greece. The features of this model are: central planning, integrated district health system with capitation financing, general physicians service. Bismarckian model has compulsory social insurance and it is included contracts with providers or patient reimbursement. This model was developed in Germany and it occurs now in Netherlands, France, Austria, Belgium, Slovakia, etc. Douglas national health insurance model is based on taxation and cost sharing between provincial and federal government. In this system the federal government regulation and provincial government administration are implemented, medical services are paid by fee-forservice and hospitals have block budgets. This system works in Canada and Australia. In mixed private/public system private insurance through employment is used, but public insurance exists for specific groups (children, elderly, poor) and private voluntary insurance is possible. This system is realized in the USA, some countries of Latin America, Asia and Africa. Semashko national health system uses revenue from state budget, it characterizes by strong central government planning and control and financing by fixed norms per population. This system was created and works in the USSR (Kostičová et al, 2011).

Nowadays the tendencies of mix and variation of these models are observed, and cost-sharing by patients contributes to health care finance in all countries of the EU (Santo et al, 2020).

Thus, for more complete characteristic of financing mechanisms of healthcare systems in the EU countries and for their comparative analysis it is insufficient just distinguish such models as: state public health care system; social health insurance system; private medicine or mixed system. Even among the countries with similar general principles of financing of public health care system there are essential differences in providing the sources and funds of national public health care system, payment for various medical services, full or part their covering, etc. That is why classification of financial mechanism must be enhanced and expanded by means including other additional principles and approaches.

It is important to design classification system based on the quantitative methods and application of the set of main indicators.

\section{THE PURPOSE AND METHODOLOGY OF RESEARCH}

The purpose of the research is cluster (or regimes of funding healthcare system) analysis and development for EU countries over long-term period.

For this study the database from Eurostat for main indicators for period of 2000-2017 was used and k-means as one of the method of cluster analysis was applied. 


\section{MAIN RESULTS}

In our research three macroeconomic indicators such as: total government expenditure on health as \% of GDP (TGEH1); total government expenditure on health as \% of total general government expenditure (TGEH2); total government expenditure on health per capita (TGEH3) were used.

Thus, first indicator TGEH1 characterizes the government policy in healthcare; second indicator TGEH2 describes budget policy and social policy of the government in its relation to healthcare; third indicator TGEH3 shows the level of economic development of the country, well-being and relative values of the expenditure on health per capita, which are higher in rich and well-developed countries.

The graphical analysis of the plots for the dynamics of the indicators TGEH1, TGEH2 and TGEH3 for each country of the EU-28 during period of 2000-2017, as well as the study of their basic descriptive statistics for mentioned indicators showed that for many countries of the EU28 the tendencies to increase values were observed. In some countries the values of these indicators were varied near average level, in other countries the more complicated changes in the values of the indicators were revealed (Dubrovina et al, 2020).

These facts proved that on the dynamics of the main macroeconomic indicators (total government expenditure on health as \% of GDP - TGEH1; total government expenditure on health as $\%$ of total general government expenditure - TGEH2; total government expenditure on health per capita - TGEH3) a lot of social, economic, political factors can have an impact. Of course, for many countries in transition, post socialist countries, which join to the EU since 2004 and later the initial values of total government expenditure on health per capita were essentially lower, in comparison with well-developed countries from Western Europe (Jakubowski, Busse 1998, Docteur, Oxley, 2003, Boulhol et al., 2012). Due to the crucial reforms in healthcare sector, structural investment programs from the EU, rapid economic growth in these countries the tendencies of the increasing total government expenditure on health per capita or total government expenditure on health as \% of GDP were observed. Nevertheless, in some countries of the EU the change in the political impact for leading political parties, political or economic crises influenced on essential changes in national models of funding healthcare (Mossialos et al, 2002, Dixon, 2006, Joumard, 2010, Eurostat, 2020).

In our research we grouped the countries of the EU-28 to similar groups or clusters according to their values of the indicators TGEH1, TGEH2 and TGEH3. For the grouping the countries of the EU-28 we used data for period of 2000-2017 and k-means method of cluster analysis. This method is described in many books devoted the applied statistical methods and is realized in such software as: Statistica, SPSS, Matlab, etc. (Borovikov, 2001, Dostal, 2008, Kozlíková, 2018). On the basis of the analysis of dendrograms and results of the analysis of variance for the different number of clusters, as well due to the results of their qualitative interpretation, we concluded that number of 5 clusters is the best variant according to the interpretation and results of the analysis of variation. The results of analysis of variation for 5 clusters are given in table 1 .

In the table 2 the descriptive statistics is shown for clusters and in table 3 the results of grouping countries of the EU-28 are presented for period of 2000-2017. 
Table 1. Analysis of Variance

\begin{tabular}{|c|c|c|c|c|c|c|}
\hline & Between & & Within & & & signif. \\
\hline & SS & df & SS & df & F & p \\
\hline X & 470,4755 & 4 & 518,6642 & 499 & 113,1596 & 0 \\
\hline Y & 945,9238 & 4 & 2235,044 & 499 & 52,79716 & 0 \\
\hline Z & $5,5 \mathrm{E}+08$ & 4 & 25739546 & 499 & 2667,019 & 0 \\
\hline
\end{tabular}

\section{Source: own elaboration in Statistica}

As it is seen from table 2, cluster No.1 contains 21 cases, this cluster characterizes the highest value of total government expenditure on health per capita (indicator TGEH3 or Z), the means for other indicators TGEH1 or X (total government expenditure on health as \% of GDP) and TGEH2 or Y (total government expenditure on health as \% of total general government expenditure) have relatively high values, but not the biggest.

Table 2. The characteristics of clusters for grouping the EU-28 countries according the different regimes of funding healthcare during period of 2000-2017

\begin{tabular}{|c|c|c|c|c|c|c|c|c|c|c|}
\hline \multirow{3}{*}{$\begin{array}{l}\frac{\mathscr{O}}{0} \\
\frac{\pi}{\pi} \\
\frac{\pi}{\pi}\end{array}$} & \multirow{2}{*}{\multicolumn{2}{|c|}{$\begin{array}{c}\text { Cluster } 1 \\
\text { Cluster contains } \\
21 \text { cases }\end{array}$}} & \multirow{2}{*}{\multicolumn{2}{|c|}{$\begin{array}{c}\text { Cluster } 2 \\
\text { Cluster contains } \\
92 \text { cases }\end{array}$}} & \multirow{2}{*}{\multicolumn{2}{|c|}{$\begin{array}{c}\text { Cluster } \mathbf{3} \\
\text { Cluster contains } \\
93 \text { cases }\end{array}$}} & \multirow{2}{*}{\multicolumn{2}{|c|}{$\begin{array}{c}\text { Cluster } 4 \\
\text { Cluster contains } \\
111 \text { cases }\end{array}$}} & \multirow{2}{*}{\multicolumn{2}{|c|}{$\begin{array}{c}\text { Cluster } \mathbf{5} \\
\text { Cluster contains } \\
187 \text { cases }\end{array}$}} \\
\hline & & & & & & & & & & \\
\hline & Mean & $\begin{array}{l}\text { Std. } \\
\text { Dev. }\end{array}$ & Mean & $\begin{array}{l}\text { Std. } \\
\text { Dev. }\end{array}$ & Mean & $\begin{array}{l}\text { Std. } \\
\text { Dev. }\end{array}$ & Mean & $\begin{array}{l}\text { Std. } \\
\text { Dev. }\end{array}$ & Mean & $\begin{array}{c}\text { Std. } \\
\text { Dev. }\end{array}$ \\
\hline $\mathrm{X}$ & 6,75 & 1,86 & 7,23 & 0,92 & 6,64 & 0,77 & 6,34 & 0,79 & 4,8 & 1,16 \\
\hline $\mathrm{Y}$ & 13,58 & 2,26 & 15,12 & 1,97 & 14,03 & 1,41 & 14,36 & 2 & 11,71 & 2,5 \\
\hline $\mathrm{Z}$ & 4007,39 & 342,64 & 2860,85 & $\begin{array}{c}251,5 \\
9\end{array}$ & 2030,03 & 237,06 & 1141,22 & 214,57 & 446,22 & 199,42 \\
\hline
\end{tabular}

Source: own elaboration in Statistica

Cluster 2 contains 92 cases, the mean of indicator TGEH1 or X (total government expenditure on health as \% of GDP) and mean of indicator TGEH2 or Y (total government expenditure on health as $\%$ of total general government expenditure) are the biggest, the countries of the EU28 with extremely high values of TGEH1 and TGEH2 were concentrated in this cluster. Also countries of the EU-28 included in this cluster have very high value of TGEH3 or Z (total government expenditure on health per capita) in comparison with countries in other clusters, such as: cluster No.4 and Cluster No.5.

Cluster 3 contains 93 cases, in this cluster are relatively high all values of indicators: TGEH1 or X (total government expenditure on health as \% of GDP,) TGEH2 or Y (total government expenditure on health as \% of total general government expenditure) and TGEH3 or Z (total government expenditure on health per capita). But the mean for indicator of TGEH3 is essentially lower than in cluster No.1 and cluster No.2, and more than 1,7 times mean value for cluster No.4, more than 4,5 times mean value for cluster No.5

Cluster 4 contains 111 cases and characterizes relatively high values for indicators TGEH1 or $\mathrm{X}$ (total government expenditure on health as \% of GDP), and TGEH2 or Y (total government expenditure on health as $\%$ of total general government expenditure), but relatively low level of TGEH3 or Z (total government expenditure on health per capita).

Cluster 5 contains 187 cases and the features of this cluster are the lowest mean values for all indicators, such as: TGEH1 or X (total government expenditure on health as \% of GDP,) 
TGEH2 or Y (total government expenditure on health as \% of total general government expenditure) and TGEH3 or Z (total government expenditure on health per capita).

It should be noted that most of the EU-28 countries switched the regimes of the funding healthcare systems. It is proved that over period of 2000-2017 they moved from one kind of cluster to another one. For most countries this switch from one type of cluster to another one occurred after long period, so it is possible to suggest the results of the economic development, new strategies of government, maybe after change of leading political party and other priorities in social or budget policies. Nevertheless, some countries demonstrated the stable policy in funding their national healthcare and over all period these countries were in the same cluster.

For example, cluster No.5 or "trap of poverty" included post socialist and emerging countries which were in this cluster all period of 2000-2017 or long period.

Such countries as: Bulgaria, Croatia, Cyprus, Latvia, Hungary and Poland were in this cluster all period of 2000-2017. Other countries were in this cluster for long period: Czechia (20002005), Estonia (2000-2014), Lithuania (2000-2016), Malta (2000-2005), Slovakia (20002007). After some improving the funding healthcare systems and increasing total government expenditure on health per capita these countries moved to cluster No.4. Thus, Greece started from cluster No.5 in 2000 to better cluster No.4, nevertheless as a reaction on the global economic and financial crisis of 2008-2012 and internal political and economic crisis this country returned to cluster No.5 in 2014 and in 2015. Portugal was in cluster No.5 in 2000 and then moved to cluster No.4. In cluster No.5 Slovenia was in 2000 and 2001, then it moved to cluster No.4.

For all period of 2000-2017 in cluster No.4 only one country was, this is Spain. In cluster No.4 a lot of countries of the EU-28 stayed long period, such as: Czechia (2006-2017), Greece (20012013, 2016, 2017), Malta (2010-2017), Portugal (2001-2017), Slovenia (2002-2017), Slovakia (2008-2017). In 2000 such countries as: Belgium, Ireland, Italy, Netherlands, Finland and the United Kingdom were in cluster No.4.

In cluster No. 3, cluster No.2 and cluster No.1 no countries were for all period of 2000-2017, nevertheless, a lot of countries were for long period. In cluster No.3 a lot of countries were for long period: France (2000-2009), Belgium (2001-2008), Italy (2004-2017), Austria (20002006), Sweden (2000-2006), the United Kingdom (2001-2013).

In cluster No.2 some countries were for long time period: Belgium (2009-2017), Ireland (20042017), Netherlands (2007-2017), Austria (2008-2016), Finland (2008-2017) and Sweden (2010-2017). Some countries of the EU-28 were in this cluster a shorter period: Denmark (2002-2007), Germany (2013-2017), Luxembourg (2003-2007), the United Kingdom (20142017).

In long period cluster No.1 with the highest level of total government expenditure on health per capita includes cases from two counties of the EU-28: Denmark (2008-2017) and Luxembourg (2008-2017). Austria had occurred in this cluster only in 2017. 


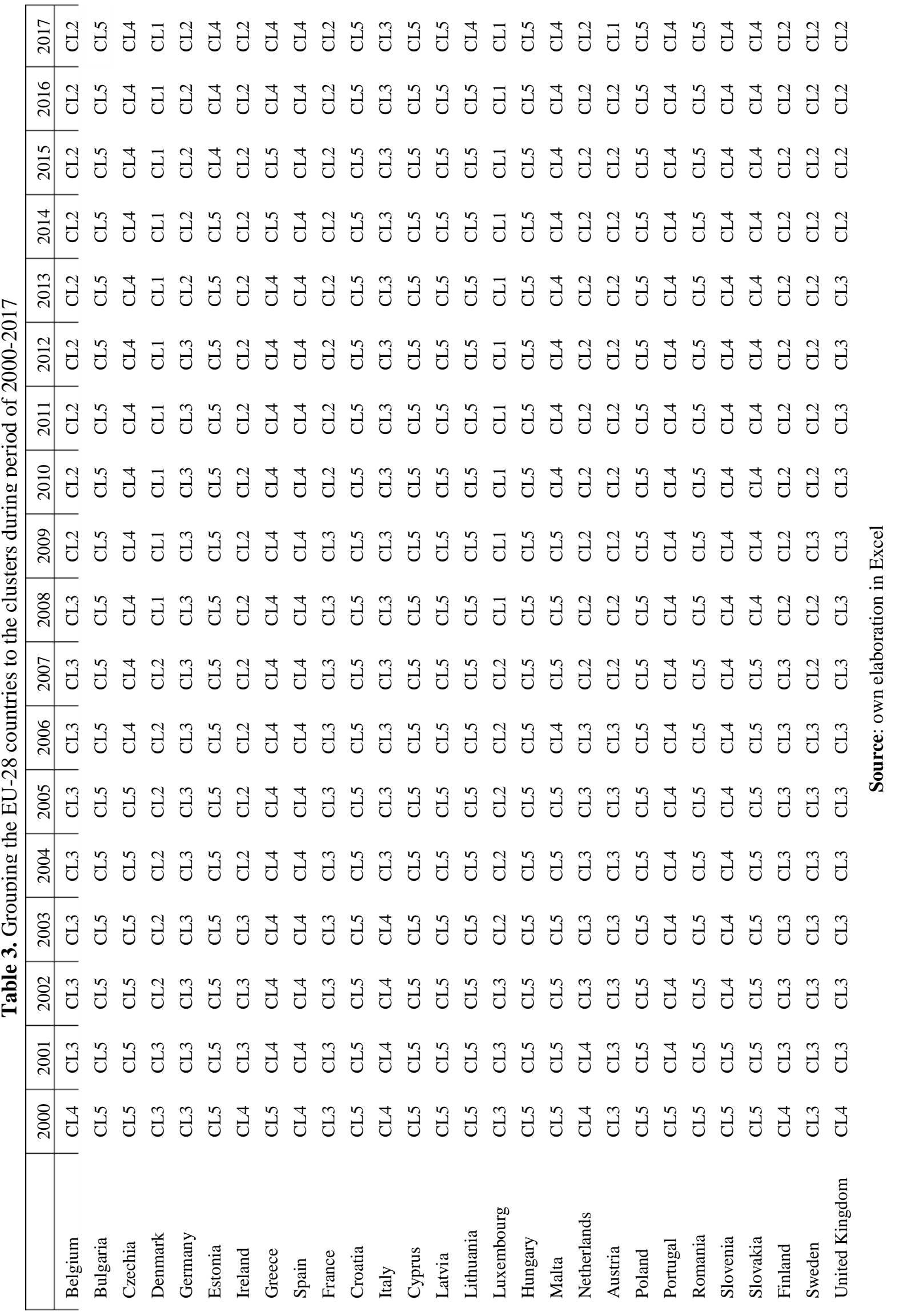




\section{CONCLUSION}

On the base of the analysis of variance for the different number of clusters, as well as results of their qualitative interpretation, we concluded that number of 5 clusters is the best variant according to the interpretation and results of the analysis of variation. For the qualitative interpretation of these clusters we called them "regimes of funding healthcare system".

It is proved that over period of 2000-2017 countries moved from one kind of cluster to another one. For most countries this switch from one type of cluster to another one occurred after long period, so it is possible to suggest the results of the economic development, new strategies of government, probably after change of leading political party and other priorities in social or budget policies. Nevertheless, some countries demonstrated the stable policy in funding their national healthcare and over all period these countries were in the same cluster.

It should be noted that in some countries the policy of financing health systems was quite flexible and changed, while in other countries this policy was stable for a long term period. At the same time, a number of social, economic, political and institutional factors influence the policy of financing health systems, which should also be taken into account and studied in connection with the changing characteristics of financing the health system in the country.

\section{ACKNOWLEDGEMENT}

The paper is the output of a scientific project IGA 3/2020-M "Improving Healthcare efficiency: new trends and challenges". (Funder: VSEMvs IGA VSEMvs, i.e. School of Economics and Management in Public Administration)

\section{REFERENCE}

Benova E., Dubrovina N., Boyko V., Zamyatin P. (2014). Classification and cluster analysis of health care systems in the OECD countries // Public Administration and Regional Development. School of Economics and Management in Public Administration. No.2. December, 2014. Vol. X, pp.45-56.

Borovikov V. (2001). Statistica: iskusstvo analiza dannych na kompjutere. - SPb.: Piter, 2001. $-656 \mathrm{~s}$.

Boulhol H. et al. (2012). Improving the Health-Care System in Poland. OECD Economics Department Working Papers, No. 957, OECD Publishing. http://dx.doi.org/10.1787/5k9b7bn5qzvd-en

Dixon A. (2006). Learning from international models of funding and delivering health care. Oxford Handbook of Public Health Practice. Oxford University Press. 2006.

Docteur E., Oxley H. (2003). Health-Care Systems: Lessons from the Reform Experience. OECD Health Working papers. No. 9, 2003.

Dostal, P. (2008). Pokročilé metody analýz a modelováni v podnikatelství a verejné správé. Brno, CERM. $340 \mathrm{~s}$.

Dubrovina N., Tulai O., Neuvauerova E. (2020). Tendencies of funding health care in EU countries: the features and perspectives/ In Monograph "Theoretical and applied aspects of sustainable development". Ed. T. Nestorenko and A. Ostenda. Katowice School of Technology. Katowice. 2020. pp. 12-22.

European Commission (2010). Joint Report on Health Systems. Occasional Papers, No. 74.

Eurostat. Database available at: https://appsso.eurostat.ec.europa.eu/nui/submitViewTableAction.do 
Funding health care: options for Europe. (2002). Edited by E. Mossialos, A. Dixon, J. Figueras, J. Kutzin. Open University Press. Philadelphia. USA, 2002. - 327 p.

Gottlieb N, Bozorgmehr K, Trummer U, Rechel B. (2019). Health policies and mixed migration - lessons learnt from the 'refugee crisis'. Health Policy 2019; 123: 805-08.

Greer SL, Hervey TK, Mackenbach JP, McKee M. (2013). Health law and policy in the European Union. Lancet 2013; 381: 1135-44.

Highest proportion of government expenditure goes to social protection and health (2020). Eurostat newsrelease No. 33/2020 from 27 February 2020. Available at: https://ec.europa.eu/eurostat/documents/2995521/10474879/2-27022020-APEN.pdf/4135f313-1e3f-6928-b1fd-816649bd424b

Jakubowski E., Busse R. (1998). Health Care Systems in the EU. A Comparative Study. Working Paper. European Parliament. Luxembourg. 1998. 130 p.

Joumard, I., C. André and C. Nicq (2010), "Health Care Systems: Efficiency and Institutions", OECD. Economics Department Working Papers, No. 769.

Kostičová M., Ozorovský V., Badalík L., Fabian G. An Introduction to Social Medicine. Bratislava, 2011. - $150 \mathrm{~s}$.

Kozlíková K, Trnka M. (2018). Úvod do spracovania a prezentovania dát v medicíne. Equlibria, s.r.o., Košice, 2018. 226 s.

Santos, J. V., Lobo, M., Neiva, R. M., Viana, J., Souza, J., Dias, C. C., Cylus, J., Ricciardi, W., \& Freitas, A. (2020). European Union state of health from 1990 to 2017: time trends and its enlargements' effects. International journal of public health, 65(2), 175-186. https://doi.org/10.1007/s00038-020-01335-0 